髄膜炎, 肝炎, マラリア, 癩, フィラリア症など 重点的にしぼられた。病原解析により, 肺炎・下 痢・髄膜炎の起炎菌の頻度を明確にしてきた。こ の仕事の中で下痢症に扔けるロタウイルスの病原 性の重要性を確認した。大腸菌ではその毒素産生 性による分類も行う。多くのウイルスが分離同定 された。インフルエンザA，B，パラインフルエ ンザ $1-3, \mathrm{RSV}$, アデノ, ポリオその他のエン テロウイルス, 麻疹, ムンプス, 単純ヘルプス, デングなどである。フィリピンでは知識としてよ く知られながら，初の分離ウイルスも多い。国内 でこれまで未経験のデータが, 自らの手で出来上 がることは，同国の研究者に強烈な感銘を与えた。 これらのデー夕は合理的な予防医学対策の基礎と なる。RITM の臨床部門は約80\%が小児で，90\% 以上が感染症であり，地域医療の奉仕とともに研 究上にも貢献している。研究部門と臨床部門を通 じて, レジデントとフェローがフィリピン大学病
院を含めた関連病院から，感染症の卒後修練に参 加し, 希望者が増加している。地域の公衆衛生活 動のための, 医師の研修も行う。医療・検査技師 の研修コースも設けている。このように次代を担 う医師をはじめ, 医療関係者の熱带病感染症の教 育訓練に，大きな役割を演じるようになってきた。

日本は建物・設備機器・専門家を提供し, これ までに紹介した研究成績に，直接関与してきた。 医学医療協力の成果は今後の自主運営と国民健康 の改善による。専門家は日本の国内発想でなく, その国のニーズに合わせて経済的で生産的，実行 可能な技術を考える必要がある。このような専門 家の育成や，帰国後の評価，身分保障などは日本 の国内的に不備な点が多く, 個人の犠牲を強いて いることがある。発展途上国への医学医療協力の ためには，当局の国際，国内的視野をもった慎重 な配慮が望まれる。

\title{
III 熱帯地における旅行者感染症
}

一その現状と対策を中心に一

\section{1 司会のことば 中林 敏夫 青木 隆一 \\ （阪大・微研・原虫） (大阪市立桃山病院)}

わが国と諸外国との交流促進に伴い，年間 450 万人もの渡航者, 200 万人もの来日者が数えられ る。特に熱带地開発途上国との国際間旅行者数は, 増加の一途をたどっている。加えて航空機輸送の 発展により, 諸外国との時間的距離が著しく短縮 した。過去十数年来, コレラ，マラリア等の輸入 感染症問題が注目され，また1969年のナイジェリ アにおけるラッサ熱の発生を契機に国際伝染病対 策の急務が叫ばれるに至った。

本シンポジウムでは単に輸入感染症問題として でなく，熱帯地旅行者にとり特に重視すべき諸感 染症をテーマとして，各分野の専門家に，発生の 現状と対策問題を中心として，解説願うこととし た。

青木博士は, 過去 3 年間の帰国者感染症患者所 見を中心に, 最近の疾病の傾向とその見解を述べ
られる。若年者の罹患が多く，腸管感染症に加え， 不明熱, 肝疾患等が注目される。

今川博士は, いわゆる国際伝染病であるラッサ 熱, マールブルク熱, エボラ出血熱について解説 される。現地の無対策現状の故に，旅行者は野鼠 との接触を避けねばならない。ワクチン開発の現 状や，Ribavirin の治療効果に触れられる。日本に おける高度安全病棟が不可欠の対応となる。

志方博士は，熱帯地に多いウイルス性肝炎問題 について，A型肝炎， B 型肝炎の他に非 $\mathrm{A}$ 非 $\mathrm{B}$ 型 肝炎を解説される。ヒマラヤに分布するものや， デル夕肝炎の特徴などにも言及される。肝炎問題 は，熱带地旅行者感染症として，ますます重要な ものとなろう。

細菌性腸管感染症に関し, 竹田博士はコレラ, および毒素原性大腸菌感染を中心に説明される。 また，多剤耐性赤痢，腸炎ビブリオ感染について の諸問題や経口輸液について述べられる。

高田博士は, マラリア発生と対策問題を解説さ れる。特にPHCに統合された新しい対策法の持 
つ特徵や，その難点に触れられる。また新治療法 や, ワクチン開発の現状を話される。

輸入熱带病の薬剤治療法に関する研究班（厚生 省）による，薬剤の供給と治験が進められてきた。 尾辻博士は自験例を中心に治療法とその効果につ いて解説され，主に，マラリア，アメーバ赤痢, 粪線虫症などの熱帯寄生虫問題を詳述される。

各演者の発表は短時間で，十分に意を尽くした 報告とはなり難いが, 広範囲に及ぶ熱帯地旅行者 感染症の重要性と, それぞれの項目について最新 の知見が述べられるものと期待している。

\section{2 帰国者における感染症の現状} 青木 隆一

(大阪市立桃山病院・感染症センター)

現今の国際化時代を反映して，わが国でも欧米 の発展国と同様に，発展途上国よりの「輸入感染 症 (imported diseases)」が急激に増加し, 防疫や 診断・治療面での新しい対応が重要視されている。 大型高速のジェット機による大量輸送時代に入っ て海外旅行者が急増し，特にインド亜大陸やアフ リカ大陸の奥地に気軽に出掛け，短時間の間に帰 国しうるようになって，現地で罹患しても潜伏期 の間に帰宅して家庭や職場に二次感染を起こした り，長期間の treking で無症状保菌者として帰国 し, 感染源となるケースも増え,「国際化時代の 落し子」として旅行者感染症, 輸入感染症対策が 強く要請されている。

1974年より1985年10月末までに大阪市立桃山病 院に入院し, 病原微生物が明らかになって確認し えた感染症患者は, 総計 383 人に達し, 複数微生 物感染は41件である。この期間を 4 年毎に 3 期に 分けると, 第 1 期は海外駐在員か長期出張者の持 ち㷌る深刻な暗い時期で, 腸チフス・パラチフス Aなどが多かった。第2 期（1978-1981）は，東 アジアか東南アジアに集団で慰安旅行に大量出掛 けるセットッアー時代で, 細菌性赤痢が急増し, また腸炎ビブリオ，サルモネラのような古典的食 中毒の多い時期であった。第 3 期 (1982-1985) は若い世代，20歳台の大学生やＯLたちが大量イ ンド覀大陸（インド，ネパール，パキスタンな ど）に，長期間の徒歩旅行を楽しむ時代（トレッ
キング時代）に入って, imported disease, 旅行者 感染症も急激に変貌し, 細菌性赤痢に加え, 新認 定の食中毒菌, Aeromonas, Campylobacter, NAGVibrio, Plesiomonasなどの「複数菌感染」が主体 を形成し, 他方, マラリアやウイルス肝炎なども 相対的に増えて来た。また海外旅行者感染症の入 院は，正月明けと夏休みに多かったが，最近では 若い大学生やO Lの春休み明け，5月の連休明け にも増え，新しい入院のピークをみるようになっ た。

旅行先, 推定䍜患地域も東アジアや東南アジア の近隣国から遠くインド亜大陸やアフリカ大陸, オセアニアや中南米に拡大され，特にインド亜大 陸が急増し, 旅行期間も $1-2$ 力月の長期のト レッキングが主流となった結果，わが国の旅行者 帰国時感染症，imported disease も大きく变貌を とげ，英国型のそれに類似するようになって来た。 このため, 英国と同様, 医療人の再教育や一般の 海外旅行者の啓発, 帰国時の健康診断の必要性が 高まり, 新しい対応が強く要請されるに至った。

3 国際伝染病一ラッサ熱, マールブルグ病, エボラ出血熱一について 今川 八束 (都立墨東病院・感染症科)

国際伝染病とは，わが国で患者の取扱い上行政 的に用いられる用語であり，ラッサ熱 (LF)， マールブルグ病 $(\mathrm{MD})$ ，およびエボラ出血熱 (EHF) をいい, LF は指定伝染病となっている。

発生状況：LF は1969年ナイジェリアで確認さ れて以来今日まで，10名以上の院内感染 6 件を含 む21件392名（死亡102名）の記録があり，ギニア から中央アフリカに至る西アフリカに, MD は 1967年ウガンダから輸入されたアフリカミドリザ ルによる感染が西独, およびユーゴスラビアで発 生して以来, 南ア, ケニア, ジンバブエ等の東, 南アフリカで 4 件 37 名 (死亡 9 名) が, EHF は 1976年スーダンとザイールでの大流行を含め 6 件 651名（死亡458名）が，ケニアを含めて報告され ている。

アフリカ以外では, LF は英国で10件10名（死 亡 2 名), 米国で 3 件 3 名（うち実験室感染 2 名 1 名死亡), と西独, オランダ, オーストラリア 
で各 1 名の輸入例があったが, 輸送中を含めて二 次感染症はなく, MD は前記西独, およびユーゴ の二次感染症を含め 31 名（死亡 7 名）の他にはな く, EHF は英国で 1 名の実験感染症が記録され ている。

ウイルス保有動物および伝播様式：ラッサウイ ルスはアフリカのサバンナに広く生息するMastomys natalensis が保有し, 尿および唾液から排 泄される。 $\mathrm{MD}$ と $\mathrm{EHF}$ ウイルスは觢齿類の保有 が疑われているもののなお不明である。ヒトへは 注射器事故のような皮虐創傷を介しての感染が主 であるが，重傷患者との濃厚接触によるエアロゾ ル感染も存在する。

臨床症状および鑑別診断：ウイルス性出血熱の 範ちゅうに入るが，発病はインフルエンザ様の非 特異症状で始まり, 臨床診断の決め手はない。最 も鑑別を要する疾患とマラリアと腸チフスである。

ウイルス学的診断：患者から長期間ウイルスが 分離されること即ち血液 (LF 19, MD 15, EHF 8 病日), 咽頭 (LF 19, MD 6 病日), 尿 (LF 32, MD 7 病日), 精液 (MD 83, EHF 61病日), 拈よ び潜伏期間の長いこと（最長 LF の 17 病日）は, 患者や接触者の取扱上問題となっている。

予防並びに治療：現在特殊療法として，それぞ れの回復期患者のプラスマの早期投与のみが有効 である。しかし1977年モザンビークで M. natalensis から分離されたアレナウイルスは，ラッサ ウイルスと免疫学的に強い交差反応を示し, サル の LF 感染防止に有効であった。又抗ウイルス剂 Ribavirinもサル LF の治療に有効であったとの報 告もあり，ともに今後の進展が期待される。

旅行者の注意：英国では1982年44名がアフリカ からの帰国後, ラッサ熱等を疑われて入院したが, うち26名はナイジェリアからで, うち2名が LF と診定された。経験上地方の病院勤務者, 調査あ るいはプロジェクトで働いている者に危険性が高 いという。

わが国の対策：患者の収容はベッドアイソレー 夕一, および $\mathrm{P} 4$ 臨床検査室を備えた都立荏原病 院の高度安全病棟に, ウイルス学的検查室は予研 村山庁舎に, 患者輸送用アイソレーターは, 成田, 大阪空港，および東京都に各 1 台用意されている。

\section{4 ウイルス性肝炎について}

志方 俊夫 (日本大・医・病理)

熱带地方に扔いてウイルス性肝炎は, 日本人の 旅行者あるいは在留邦人にとって腸管感染症につ いで多発する疾患であり，無視できない重要な病 気である。B型肝炎とは潜伏期が長いので，これ らの地方への旅行と直接の関係を証明するのが困 難なことがある。

ウイルス性肝炎は感染症の中でその解決がもっ とも遅れたものの一つであるが, これはその起因 ウイルスが，長い間見つからなかったためである。 しかし Blunberg のオーストラリア抗原の発見を 契機にして，まずB型肝炎ウイルスが見つかり， ついでA型肝炎ウイルスも見つかった。しかしA 型と B型肝炎の確定診断が出来るようになると, $\mathrm{A}$ 型でも $\mathrm{B}$ 型でもない肝炎の存在がはっきりして きたのである。これを現在仮に非 $\mathrm{A}$ 非 $\mathrm{B}$ 型肝炎と 呼んでいるが，この中には日本など先進国で輸血 などに関連して見られる非 $\mathrm{A}$ 非 $\mathrm{B}$ 型肝炎と，イン ド,ビルマなどヒマラヤ山簏の国々で見られ，経 口感染で伝播する非 $\mathrm{A}$ 非 $\mathrm{B}$ 型肝炎とがある。また B 型肝炎ウイルスをへルパーウイルスとして感染 する，デルタウイルスも問題になる。ここでは 個々のウイルスの感染経路，予防法などを簡単に 述べた。

$\mathrm{A}$ 型肝炎は日本国内では戦後急速に隇少し, 日 本人の 35 歳以下の人は，5\%位しか抗体を持って いない。熱帯地域では今なお常在しているが，A 型肝炎に対して抗体のない日本の若い人がこれら の地域に行くと，またたく間にA型肝炎に感染す る。A型肝炎は子供が感染した場合は軽くかかる が, 成人が感染すると重くなるという事もある。

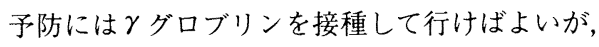
ワクチンはまだ出来ていない。

B 型肝炎は日本国内でもまだあるが, 東南アジ ア，アフリカでは HBV のキャリヤー率が高く, 日本にいるより感染する機会は多い。感染は医療 機関で起こる事もあるが, 性行為により主として 感染する。成人が感染した場合急性肝炎ですむが, 家族を伴って海外に赴任し子供が感染した場合, 将来肝硬変, 肝癌になる事がある。ワクチンは既 
に出来ているが，ワクチンの接種に 6 力月かかる 事を考えておかなければならない。

デルタウイルスは，B型肝炎ウイルスをヘル パーウイルスとして同時に感染する。ただデルタ ウイルスの混合感染があると症状が重くなり, し ばしば激症肝炎で死亡するから注意をしなければ いけない。

主として輸血で感染する非 $\mathrm{A}$ 非B型肝炎は，む しろ日本国内で感染する事のほうが多いかもしれ ないが, 熱帯地域でも医療機関で感染する機会は ある。

経口的に伝播する非 A 非B型肝炎は, インド, ビルマを始めヒマラヤの山麓の地域にみられる。 経口的に感染し，しばしば流行する。妊婦あるい はB型肝炎ウイルスのキャリヤーが感染すると症 状が重くなり，死亡率が高い。

\section{5 細菌性腸管感染症}

竹田 美文 (東大・医科研・細菌感染)

熱帯や亜熱帯地方への旅行者が，旅行中に下痢 を訴えることはかなり古くから知られている。た とえば, Montezuma's revenge という言葉は，旅 行者下痢症を意味するが，これはメキシコの Aztec 族最後の皇帝であった Montezuma II 世 （1503-1520）を攻めた軍隊が，下痢が原因で戦 意を失い敗退したところから，下痢のことを皇帝 の復しゅう (revenge) であると恐れたことに由 来しているといわれる。

大阪空港検疫所における旅行者下痢症の原因菌 検索成績によると，わが国の海外旅行者の旅行者 下痢症のうち，もっとも多いのは毒素原性大腸菌 感染症で, 次いでサルモネラ症, 腸炎ビブリオ感 染症が多い。この 3 つが, 原因の確定した細菌性 腸管感染症の約 $90 \%$ を占める。赤痢やコレラは, 前 3 者に比べると患者数は少ない。しかし熱帯地 においては, 細菌性腸管感染症としては, 前 3 者 よりも重要である。わが国においても，法定伝染 病であるところから, より慎重な取り扱いが要求 されている。

1961年よりはじまった現在のコレラの第 7 次世 界大流行は，ますます拡大する傾向が強く，終息 する気配がない。流行の主要菌型はエルトール型
菌であるが，1982年秋からバングラデシュにおい て古典型菌の流行が繰り返されている。古典型菌 によるコレラは, 一般的にいって，エルトール型 菌によるコレラよりも重症の場合が多く, 治療を 施さなかった場合の致命率も，前者の方がはるか に高い。わが国では，1977年の有田市における流 行以来, 毎年数十名のエルトール型菌によるコレ ラが報告されている。その殆どが海外旅行者であ る。

毒素原性大腸菌が旅行者下痢症の原因菌として 極めて重要であることは，1975年頃から広く認め られるようになった。わが国の旅行者下痢症にお いても，その約20～25\%が毒素原性大腸菌による ことがわかっている。国内でも集団食中毒事例ゃ 散発事例の発生が相ついで報告されているが, こ れらが国外から持ち込んだ囷による可能性が少な くない。早急な対策が必要である。

コレラや毒素原性大腸菌感染症の場合に見られ る水様性下痢の治療に, WHO の推奨する経口輸 液 (Oral Rehydration Solution, ORS) が開発途上 国では広く使用されていて，めざましい治療効果 を挙げている。組成は 1 リットル当たり, 食塩 $3.5 \mathrm{~g}$, 重炭酸ソーダ $2.5 \mathrm{~g}$, 塩化カリウム $1.5 \mathrm{~g}$, グルコース $20.0 \mathrm{~g}$ から成っている。原因菌の除 去には役立たないが，対症治療剂として，旅行者 が簡単に使用できる利点がある。わが国において も, 旅行者下痢症のみでなく, 一般の臨床でも広 く利用することを検討すべきであろう。

6 マラリアについて

高田季久（大阪市大・医・医動物）

WHO の指導による MEP (Malaria Eradication Programme) は当初は素晴らしい成果を収め, 20 カ国以上でマラリアが根絶された。しかし1960年 代末から1970年代にかけて, 熱帯各地で激しい再 燃が起こり，場所によっては MEP 開始以前とあ まり変わらない程の流行がみられる場所さえ出て 来た。

1985年の WHO の報告によると，1983年の世界 の総人口 46 億 7600 万人うち, マラリア污染地区 に住居する人々は, 約半数以上の 26 億 1600 万人で ある。そして毎年 2 億人以上のマラリア患者と 
200万人以上の死者があるものと推定されている。

この再燃の原因については, 経済的な破綻, 媒 介蚊の殺虫剤抵抗性, 原虫の薬剤耐性など, 多く の要因が関与しているが，いずれにしても污染地 区ではマラリアによる生産性の低下が貧困を増大 し, 非污染地区では旅行者による輸入マラリア症 例と死亡例の増加が大きな問題となっている。

この様な再燃に対して WHO は1970年代中頃に MEP から MCP (Malaria Control Programme) の作戦変更を行うと共に，1970年代末に MCPを 4 種の戦術様式に区分し, 当面各地の実情に応じ た実行可能な方法で実施することとし，さらに MCP を各国の PHC (Primary Health Care) 組織 に統合して実施するように勧告した。そして熱帯 地への旅行者の安全のための指針として, 毎年世 界各地のマラリアの現状と予防法をまとめた “Malaria Risk in International Travel”を公表して いる。

一方実施面では, かつて成虫蚊対策と患者の発 見治療を主体とした対策に改善が加えられ, 幼虫 対策をも含む各地区に適した方法を採用すること とし, 同時に新しい殺虫剤や抗マラリア剂の開発 など, MCP に関する各種の基礎的, 応用的研究 が世界的規模で推進された。

その結果1980年代には, アフリカを除く世界の マラリアは, 1970年代に比して徐々に低下する傾 向を示している。各種の基礎的研究の中でも Biotechnology を応用したマラリアワクチンの研 究の進歩は特筆すべきものではあるが, 残念なが ら未だ応用の域には達していない。

最近マラリアの予防に関して大きな問題となっ ているのは, 従来 Chloroquine 耐性熱帯熱マラリ ア污染地区で広く用いられていた，Fansidar+ Chloroquine 併用予防内服を行った米人旅行者の 中に激しい皮虔壊死, 発赤, Stevens-Johnson 症 候を示すものが多発し，6名が死亡したことが米 国 CDCにより明らかにされたことで，WHO もこの点を重視し, Fansidarなどの合剤の予防 内服は慎重に行うように勧告している (Wkly. Epidem. Rec., 60, 181-188, 1985; MMWR., 34, 185-194, 1985)。

わが国では幸いにまだこの様な報告はないが,
かなりの旅行者が Fansider, 又は類似合剤を予防 内服しているものと思われるので, 今後 WHO, $\mathrm{CDC}$ などの勧告を参考として，日本人に適した 予防対策の立案, 旅行者の追跡調査, 輸入マラリ ア症例の確実な捕捉などのための組織作りが必要 と考えられる。

\section{7 治療薬剤からみた熱帯性寄生虫病}

尾辻 義人 (鹿巟島大·医・二内科)

海外との交流が盛んになるにつれて, 輸入熱帯 病の問題はますます重要性を増している。

わが国においては, 現在寄生虫病薬は需要の減 少と副作用という問題で, 入手困難な状況が続い ている。

このような寄生虫病薬の入手困難を解消する目 的で，1980年度に輸入熱帯病の薬物治療法に関す る研究班が結成され, 輸入寄生虫病に対する治療 薬剤の入手, 保管, 配布および治療効果, 副作用 などの検討を続けている。最近までの成績をまと めて報告する。

1980年度より1985年 6 月までに治療薬剤を配布 した件数は506件で, 都, 府, 県別にみると, 東 京都105件, 鹿児島県101件, 福岡県67件, 大阪府 45件と多く，おおむね全国各地に配布している。

さらに, 疾患別では, マラリアが144件, 糞線 虫症 119 件, 鞭虫症 40 件, 旋毛虫症 35 件, 肝吸虫 症35件, カリ二肺炎19件, 広節裂頭条虫症19件, アメーバ赤痢16件, ランブル鞭毛虫症15件などが 多かった。

治療薬剤では, サイアベンダゾールに次いで, マラリア治療薬のプリマキン, クロロキン, ファ ンシダールが多く，その他メベンダゾール，プラ ジンカンテル，キナクリンなどの要望が多かった。 治療薬凨の医療機関別では大学が191件, 国公 立病院164件, 私立病院52件であった。

次に輸入寄生虫は176件で，マラリアが133件と 最も多く，日本人が103件，外国人が 30 件であっ た。また鞭虫症13件, 肝吸虫症11件, ランブル鞭 毛虫症 9 件でその他トリパノソーマ症, 日本住血 吸虫症, ビルハルツ住血吸虫症, 旋毛虫症, 無鈎 条虫症などであった。 次にマラリア患者について検討した。マラリア 
患者133件中, 年齢別では30歳代55件, 20 歳代 46 件で, 若者が大部分であった。マラリアの種別で は三日熱マラリア 67 件, 熱帯熱マラリア32件, 四 日熱マラリア 1 件, 種別不明 3 件であった。感染 地は日本人ではアジア地区 45 件, アフリカ地区 42 件, ニューギニアを含むオセアニア地区14件, 不 詳 2 件, 外国人ではアジア地区 22 件と最も多く,
次いでアフリカ地区 4 件であった。マラリア患者 の業務内容では日本人は観光 23 件, 学術調査 15 件 のほか海外での業務の関係が目だった。外国人で はベトナム難民 7 件が目だっていた。

以上より, 輸入熱帯性寄生虫病問題と治療薬剤 の入手を容易にすることは, 緊急な問題である事 を痛感した。 


\title{
Infectious diseases of international travelers in the tropics -present status of epidemiology and control
}

\section{INTRODUCTORY REMARKS}

\author{
TOSHIO NAKABAYASHI ${ }^{1}$ AND TAKAKAZU AOKI ${ }^{2}$ \\ Research Institute for Microbial Diseases, Osaka University ${ }^{1}$ \\ and The Infectious Disease Center, Osaka Momoyama Hospital ${ }^{2}$
}

Recently, oversea travelers and foreign visitors to Japan have greatly increased in number. Travelers in the tropics have also had increased chances of being infected with diseases of various origins; viral, bacterial, protozoan and parasitic. In this symposium, infectious diseases of particular importance for international travelers in the tropics will be presented by several experts with special focus of epidemiology and control measures.

\section{THE CURRENT STATES OF IMPORTED DISEASE AT THE INFECTIOUS DISEASE CENTER, OSAKA MOMOYAMA HOSPITAL}

\section{TAKAKAZU AOKI}

The Infectious Disease Center, Osaka Momoyama Hospital

Since the beginning of 1974 , the studies on imported diseases in inpatients at our center have been done and reported successively. Almost all of these patients were returningtravellers suffered from acute infectious diseases, so-called "travellers diarrhea", FUO (Fever of Unknown Origin) and jaundice.

Recently, these imported diseases at our hospital are changing into infectious diseases resembled to the "United Kingdoms type". For this reason, the numbers of these imported diseases inpatiants travelled as "Treking" in the rural districts to Indian Subcontinent and African Continent. The current states of imported diseases in returning-travellers were presented. 


\title{
3 INTERNATIONAL INFECTIOUS DISEASE - LASSA FEVER, MARBURG DISEASE, EBORA HAEMORRHAGIC FEVER
}

\author{
YATSUKA IMAGAWA \\ Department of Infectious Disease, Tokyo Metropolitan Bokuto Hospital
}

\begin{abstract}
"International infectious disease", which is the administractive term dealing with a patient in Japan, is indicated of lassa fever (LF), marburg disease (MD) and ebora haemorrhagic fever (EHF) and LF is regulated under the infectious disease prevention law.

Occurrence: LF is exist in West Africa (Guinea to Central Africa), MD in East and South Africa and EHF in Zaile, Sudan, Central Africa Republic and Kenya. Except for Africa, LF was occurred in 10 cases ( 2 cases died) in England, 3 cases in America (laboratory acquired infection of 2 cases and 1 death), each one case in West Germany, Netherlands and Australia. These were not secondary infections including transportation but imported cases. There was no occurrence of MD except for the incidense of secondary infection (7 died out of 31 cases) caused by imported African green monkey from Uganda on West Germany and Yugoslavia in 1967. There was one laboratory acquired infection with EHF in England.

Animal reservoir and transmission: It is confirmed that LF is carried by Mastomys natalensis inhabiting widely at the area of Savanna and the virus is excreted from urine and saliva. MD and EHF are suspected that they are carried by rodents but yet unconfirmed. On the infectious route to human, it is mainly through needle stick or other penetrating injury with the patient's blood or excreta but is possible to aerosol infection by a close contact with severe patients.
\end{abstract}

Clinical symptoms and differential diagnosis: These diseases belong to the viral haemorrhagic fever, and their attacks started with non-specific symptoms like influenza. But there is no conclusive factor in the clinical diagnosis of these diseases. The diseases to be differentiated are malaria and typhoid fever.

Viral diagnosis: It becomes problems on dealing with the patient and the contact in cooperation with long incubation period (the longest is 17 days in LF) and the illness day of virus isolation from blood (LF in 19, MD in 15, EHF in 8), urine (LF in 32, MD in 7), pharynx (LF in 19, MD in 6), semen (MD in 83, EHF in 61).

Prevention and treatment: Arenavirus, which was separated from M.natalensis at Mozambique in 1977, showing close immunological cross reaction with lassavirus, have weak infectious ability to monkey, and is effective for prevention of attack in LF with monkey. It is expected that Ribavirin could be also effective against LF with monkey by the future development.

Caution for travelers: In England in 1982, there were found 44 cases of viral haemorrhagic fever after return from Africa, and 2 cases were confirmed as lassa fever. It proved experimentaly that the man, who engage in the local hospital, various researches and projects at the rural area.

Management in Japan: As the accomodations of patients in Japan, there are a high security ward with isolater and clinical laboratory in Tokyo Metropolitan Ebara Hospital, a examination institute on virology in National Institute of Health and transit isolaters in each Narita and Osaka 
Airports and Tokyo Metropolitan.

\title{
4 VIRAL HEPATITIS IN TROPICAL AREAS
}

\author{
TOSHIO SHIKATA
}

Department of Pathology, Nihon University School of Medicine

Several hepatitis viruses cause viral hepatitis in human beings. Clinical symptoms and histological features are quite same between various hepatitis caused by different viruses, such as, hepatitis A virus, B virus, $\delta$ virus and non-A, non-B viruses. Hepatitis A and one kind of non- $A$, non- $B$ hepatitis virus only causes acute hepatitis by transient infection, whereas, hepatitis $B$ and other non-A, non-B viruses cause not only acute hepatitis but also chronic hepatitis, liver cirrhosis and hepatocellular carcinoma by persistent infection. Prevalance of hapatitis A is very high in tropical areas and prevalance of hepatitis B is high in Asian-African countries.

\section{BACTERIAL ENTERIC INFECTIONS}

\author{
YOSHIFUMI TAKEDA \\ Department of Bacterial Infection, The Institute of Medical Science, \\ The University of Tokyo
}

Epidemiological study at Osaka Airport Quarantine Station shows that the most prevalent bacterium causing traveller's diarrhea in oversea travellers in our country is enterotoxigenic Escherichia coli, followed by Salmonellae and Vibrio parahaemolyticus. About $90 \%$ of traveller's diarrhea caused by bacteria are due to infections of these 3 bacteria. Compared with these, rates of isolation of Shigellae and Vibrio cholerae are very low, but these 2 bacteria are important in tropical countries. Also these 2 bacteria, should be handled with special care as these are controled by a law in our country.

Present global pandemic of cholera has been mainly due to $V$. cholerae biotype eltor. However, V. cholerae biotype classical has reappeared in Bangladesh in the autumn of 1982 . It would be possible that classical $V$. cholerae might spread out of West Bengal to other areas of the world in future.

Importance of enterotoxigenic E. coli as a causative agent of traveller's diarrhea has been recognized since around 1975 . It has been reported that about $20-25 \%$ of patients of traveller's diarrhea in our country are due to enterotoxigenic E. coli. Sporadic diarrheal cases and food poisoning due to enterotoxigenic $E$. coli have also been reported.

Oral rehydration therapy, recommended by World Health Organization, which has been becoming popular in developing countries, is not applied to patients of traveller's diarrhea in our country. Since the oral rehydration solution is easy to handle for oversea travellers, the knowledge and advantages of oral rehydration therapy should be advocated in medical society. 


\title{
6 ON MALARIA
}

\author{
SUEHISA TAKADA \\ Department of Medical Zoology, Osaka City University Medical School
}

Owing to the effort of MEP (Malaria Eradication Programme), marked reduction of malaria morbidity and mortality had occurred on a world wide scale, and the objective of malaria eradication had been achieved in more than 20 countries or areas by year 1970 . However, since the late 1960's the malaria situation had progressively deteriorated in many tropical countries and in some countries the malaria resurgence had shown epidemic situations in the middle of 1970's. According to the information of WHO, in 1983 more than half of the world's population-some 2,616 million people (56\%)-lived in the malaria endemic area, and about 389 million people (8\%) inhabit areas where no specific measures are undertaken to control malaria transmission and where the prevalence of infection has hardly changed. Thus in endemic countries, malaria threaten not only the health of inhibitants but also the socioeconomic development of the communities, and in malaria free countries the increasing cases and deaths of imported malaria from endemic areas are annoying problems.

At present malaria parasites are developing resistance to the antimalaria drugs, and the vector mosquitoes are becoming resistant to DDT and other insecticides. Behavioural changes of vector mosquito, such as avoidance of contact with insecticide sprayed wall, are also serious problems in malaria control. Against the serious resurgence, in the middle of 1970's WHO has revised the antimalaria strategy from Malaria Eradication Programme (MEP) to Malaria Control Programme (MCP) and defined technical and operational approach to malaria control, and in 1978 WHO recommended the inclusion of antimalaria campaigns in national health programme or primary health care. Four tactical variants were also recommended to choose the most suitable and feasible combination of control methods in each endemic country.

Annual WHO reports, on world malaria situation and on malaria risk in international travel, are quite useful informations for us to guide the travellers how to prevent this disease. On the other hand, basic and applied researches for malaria control were encouraged and supported by WHO during past 20 years and are obtaining various creditable results. Recent report of 6 deaths from severe cutaneous reactions in American travellers who were taking Fansidar with chloroquine for chemoprophylaxis of $P$. falciparum infection has embarrassed us greatly (Wkly. Epidem. Rec. 60, 181, 1985; MMWR. 34, 185, 1985). Both WHO and CDC in USA have recommended judicious use of chemoprophylactic drugs for prevention of malaria infection in travellers to endemic areas. Although we not yet have such severe cases in Japan, considerable numbers of Japanese travellers to malarious areas are suspected to be using Fansidar or similar drugs.

For prevention of malaria infection in Japanese travellers, it is urgently requested in Japan to establish an organization which is responsible for planning the suitable method for malaria prevention, follow up survey of travellers to malaria endemic areas and for collection of accurate data of imported malaria cases in Japan. 


\title{
7 PRESENT STATE OF TROPICAL PARASITIC DISEASES IN VIEW OF THERAPEUTIC DRUGS
}

\author{
Yoshinito OTSUJI \\ The Second Department of Internal Medicine, Faculty of Medicine, \\ Kagoshima University
}

As an interchange of personnel between Japan and foreign countries becomes more frequent so-called importation of tropical diseases has turned up as an important issue to be solved. In our country, on the other hand, difficulty to obtain therapeutic drugs for the tropical parasitic diseases has became a serious problem. In order to improve the situation a task force for studing therapeutic drugs for the imported tropical diseases was formed and means of procurement, safekeeping, dispensing, treatment effects and side effects of the drugs have been investigated.

Results accomplished during 1980-1985 are: 1) The drugs have been forwarded on request to medical institutions on 506 occasions covering the whole country. 2) Breakdown of the imported diseases revealed 144 malaria cases at the top on the list, followed by 119 strongyloidiasis, 40 trichocephaliasis, trichinosis, clonorchiasis, carinii pneumonia, latum diphyllobothriasis, amebic dysentry and lambliasis, in that order. 3) Drugs that have been in great demand are thyabendazole, primaquine, fansider, mebendazole, praziquantel and quinimax. 4) Medical institutions that have been in need of the drugs were university hospitals on 191 occasions, national and other public hospitals on 164 occasions and private hospitals on 52 occasions. 5) There have been 176 cases of imported parasitic diseases with 133 malarial cases topping the list followed by 13 strongyloidiasis, 11 chlonorchiasis, 9 lambliasis in addition to trypanosomiasis, schistosomiasis japonica, urinary schistosomiasis (Bilharz), trichinosis and saginata taeniasis. 6) There were 133 malarial cases with 103 Japanese patients and 30 foreigners. Age distribution of the patients showed higher incidence among younger generations with 55 cases among those in thirties and 46 in twenties. The malarial cases included 67 vivax, 32 tropical, one malariae and 3 unknown species malaria cases. Places of malaria infection for Japanese travellers were Asian region (45 cases), African region (42) and Oceanian region including New Guinea (14). We could not, however, trace original places of infection for 2 cases.

It has been keenly felt that issues of imported tropical parasitic diseases and realization of being able to procure therapeutic drugs in need without delay should be given utmost attention. 